\title{
Localized endometrioid cancer in the abdominal wall with synchronous early-stage endometrial cancer
}

\section{Batın duvarinda erken evre endometrium kanseri ile senkron lokalize endometrioid kanser}

\author{
(1) Orhan Şahin ${ }^{1}$, (1) Nedim Tokgözoğlu1 ${ }^{1}$, (1) Tolga Taşcı ${ }^{2}$ \\ ${ }^{1}$ University of Health Sciences Turkey, Prof. Dr. Cemil Taşçoğlu City Hospital, Department of Obstetrics and Gynecology, İstanbul, Turkey \\ ${ }^{2}$ Bahcesehir University Faculty of Medicine, Department of Obstetrics and Gynecology, İstanbul, Turkey
}

\begin{abstract}
Presented herein is the only case in literature with the synchronous development of endometrioid-type endometrium cancer and endometrioid carcinoma originating from the endometriosis foci in a scar tissue. A 44-year-old female patient presented with complaints of abnormal uterine bleeding, swelling at the rectus muscle level in the abdominal wall, and cyclic pain close to the old cesarean section incision scar. Pathological findings of the rectus muscle and endometrial biopsies revealed endometrioid adenocarcinoma (grades 2 and 1, respectively). Positron emission tomography, performed for primary focus investigation, revealed pathologic fluorodeoxyglucose uptake in the uterine cavity and biopsy site, consistent with residual tumor without any pathologic uptake elsewhere. The patient underwent total abdominal hysterectomy, bilateral salpingo-oophorectomy, and systematic pelvic and para-aortic lymphadenectomy, and the residual tumor in the left rectus muscle was excised. The patient was followed up for 3 years. At a postoperative follow-up in the $4^{\text {th }}$ year, no relapsed tumor or metastasis was seen on imaging.
\end{abstract}

Keywords: Endometriosis, endometrioid adenocarcinoma, scar

Öz

Endometriozis, ovaryan hormon uyarımına yanıt veren, uterus boşluğunun dışına implante olmuş bezler, stroma ve endometriyal dokunun varlığı ile karakterizedir. Endometrioid tip endometrium kanseri ve endometrioid karsinomun skar dokusunda endometriozis odaklarından kaynaklanan senkron gelişimi olan tek olguyu literatürde sunduk. Kırk dört yaşında kadın hasta, anormal uterin kanama, karın duvarında rektus kası seviyesinde şişlik ve eski sezaryen kesi izine yakın siklik ağrı şikayetleri ile başvurdu. Rektus kası patolojik bulguları ve endometriyal biyopsiler endometrioid adenokarsinomunu (sırasıyla; grade 2 ve 1) gösterdi. Birincil odağın araştırılması için gerçekleştirilen pozitron emisyon tomografisi, başka bir yerde herhangi bir patolojik tutulum olmaksızın tümör ile uyumlu olarak uterin kavite ve biyopsi bölgelerinde patolojik florodeoksiglukoz tutulumunu ortaya çıkardı. Hastaya total abdominal histerektomi, bilateral salpingo-ooferektomi, sistematik pelvik ve paraaortik lenfadenektomi yapıldı ve sol rektus kasındaki rezidüel tümör eksize edildi. Hasta üç yll takip edildi. Postoperatif 4. yllda görüntülemede nükseden tümör veya metastaz görülmedi.

Anahtar Kelimeler: Endometriozis, endometrioid adenokanser, skar

\section{Introduction}

Endometriosis is characterized by the presence of endometrial tissue with glands and stroma implanted outside the uterine cavity, which respond to ovarian hormone stimulation ${ }^{(1)}$. The disease affects at least 10\% of women with a child-bearing potential in the United States ${ }^{(2)}$. Despite its high prevalence, its etiology remains unclear. Pelvic endometriosis is nowadays a common condition encountered by gynecologists and infertility specialists. Extrapelvic endometriosis in distant sites, such as the urinary bladder, umbilicus, gastrointestinal tract, and thoracic cavity, is a rare condition. Even rarer is scar endometriosis; its pathology is different from other locations of endometriosis. Scar endometriosis occurs due to the iatrogenic implantation of endometrial tissue during uterine procedures and very rarely after non-uterine procedures. The incidence of scar endometriosis after a cesarean section (C-section) has been reported to be $0.03-0.4 \%{ }^{(3)}$. The mean time interval between a previous uterine surgery and the diagnosis of abdominal wall endometriosis was found to be $2.3 \pm 2.2$ years $^{(4)}$. Herein, we report the case of a patient with endometrioid adenocarcinoma

Address for Correspondence/Yazışma Adresi: Orhan Şahin MD,

University of Health Sciences Turkey, Prof. Dr. Cemil Taş̧̧ı̆̆lu City Hospital, Clinic of Obstetrics and Gynecology, İstanbul, Turkey

Phone: +90 5322400012 E-mail: drorhansahin@gmail.com ORCID ID: orcid.org/0000-0002-7216-3816

Received/Geliș Tarihi: 24.06.2021 Accepted/Kabul Tarihi: 12.07.2021

${ }^{\oplus}$ Copyright 2021 by Turkish Society of Obstetrics and Gynecology

Turkish Journal of Obstetrics and Gynecology published by Galenos Publishing House. 
that arose in a focus of extrapelvic endometriosis. This case report was edited according to the CARE guideline ${ }^{(5)}$.

\section{Case Presentation}

A 44-year-old female patient presented to a healthcare institution with swelling at the rectus muscle level in the abdominal wall between the left side of the umbilicus and previous C-section incision scar that progressively enlarged within the last 6 months. The patient also complained of menorrhagia. Incisional biopsy of the patient's rectus muscle and endometrial biopsy were performed simultaneously. Pathological findings of the rectus muscle and endometrial biopsies revealed endometrioid adenocarcinoma (grades 2 and 1, respectively) (shown in Figure 1). The patient had undergone C-section twice in the past. Positron emission tomography (PET)/computed tomography, performed for primary focus investigation, revealed pathologic fluorodeoxyglucose uptake in the uterine cavity and biopsy site, consistent with the findings of the residual tumor, without any pathologic uptake elsewhere (Figure 1). Gynecological examination revealed no pathological changes. A transvaginal ultrasound (US) study showed irregular thickening (up to $20 \mathrm{~mm}$ ) of the endometrial cavity. As a result of sonographic evaluation, tumor was considered to have infiltrated less than half of the myometrium thickness. The result of CA-125 test was within the reference range. The patient underwent total abdominal hysterectomy, bilateral salpingo-oophorectomy,

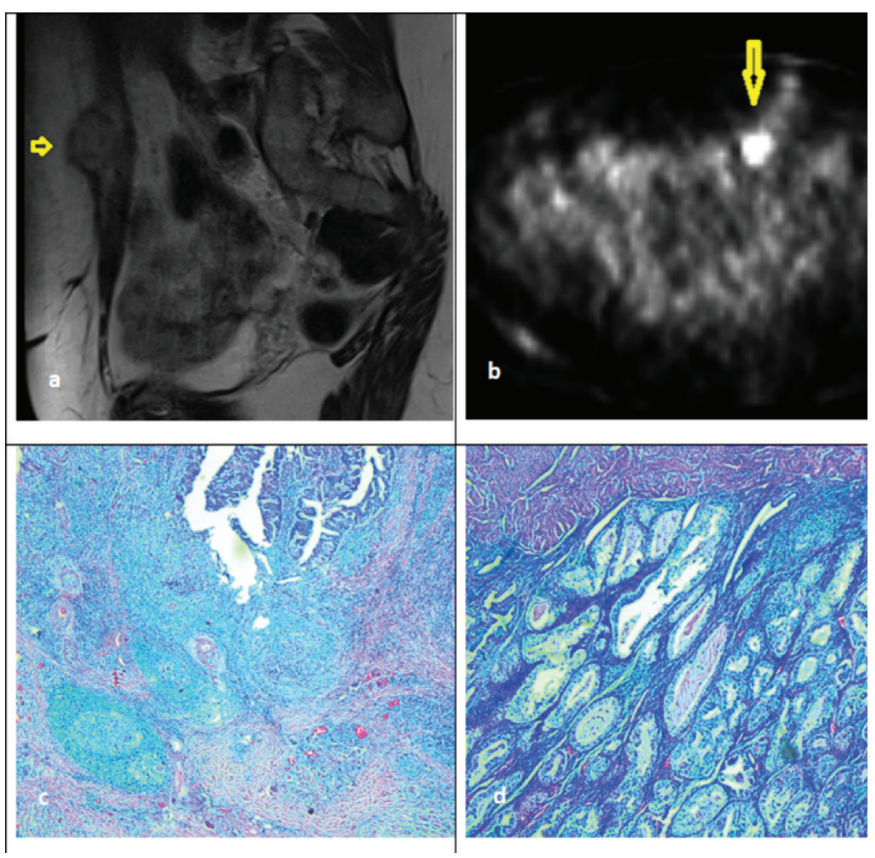

Figure 1. a) Axial section of anterior abdominal wall magnetic resonance imaging, arrow shows residual tumor nodule, b) A positron emission tomography scan showing a residual tumor on the anterior abdominal wall, arrow shows residual tumor on the anterior abdominal wall, c) Pathologic image of endometrioid grade II tumor on the anterior abdominal wall, d) Pathologic image of endometrioid endometrial grade I tumor and systematic pelvic and para-aortic lymphadenectomy, and the residual tumor in the left rectus muscle was excised. No signs of peritoneal endometriosis were observed. In addition, postoperative complications were absent, and the patient was discharged from the hospital on the $4^{\text {th }}$ postoperative day. Pathological definitive diagnosis was stage-IA FIGO grade I, lymph-vascular space invasion negative, tumor invasion depth of $0.8 \mathrm{~cm}$, size of $1.8 \mathrm{~cm}$, and endometrioid-type endometrial adenocarcinoma; the rectus muscle excision specimen revealed grade II endometrial-type adenocarcinoma in a background of endometriosis with intact surgical margins. This case was discussed by the attending physicians at the multidisciplinary gynecologic oncology tumor board. Chemoradiotherapy was given as four cycles of carboplatin + paclitaxel combination, and radiotherapy administration was planned due to the poor malignant transformation prognosis of endometriosis in the abdominal wall. The patient was given a total of $50 \mathrm{~Gy}$ externalbeam radiotherapy at a dose of 1.8 Gy once a day using the volumetric arc therapy method for 28 days. The patient was followed up for 3 years. At a postoperative follow-up in the $4^{\text {th }}$ year, no relapsed tumor or metastasis was seen on imaging. The patient was recommended to continue follow-up at every 6 months.

\section{Discussion}

This is the only case report in literature with the synchronous development of endometrioid-type endometrium cancer and endometrioid carcinoma originating from the endometriosis foci in a scar tissue. Endometriosis in a scar tissue starts with the formation of functional endometrium tissue followed by the inoculation of dropped endometrial cells into the subcutaneous or subfascial tissue inside the incision. Periodic pain and swelling in the scar tissue or surrounding nodular lesion during menstrual cycle without dysmenorrhea or pelvic pain are suggestive of scar endometriosis. It is usually located in C-section scar and inside rectus sheath until linea alba level or in subcutaneous space inside the incision scar; however, scar endometriosis in different sites such as trocar inlet, episiotomy scar, and appendectomy scar has also been reported ${ }^{(3)}$. Malignant transformation of endometriosis associated with surgical scars is extremely rare, with an estimated incidence below $0.3-1.0 \%$, and $80 \%$ of endometriosis-related cancers are referred to the ovary $^{(6)}$.

Mihailovici et al. ${ }^{(7)}$ analyzed data from 48 cases with endometriosis-associated abdominal wall cancer. All patients had undergone a uterine surgery, mainly $\mathrm{C}$-section. The mean time between the first uterine surgery and cancer diagnosis was $19( \pm 8)$ years. The patient reported in our study had undergone C-section twice, i.e., 5 and 10 years prior to cancer diagnosis. However, the tumor progressively enlarged inside the abdominal wall within 6 months before diagnosis and caused symptoms. Possible underlying malignancy should be considered in endometriotic foci with progressive growth. Patient's history 
and results from biopsy specimen help to make a diagnosis, and US and magnetic resonance imaging studies are utilized for imaging.

In our case, the distinction between metastasis and synchronous tumor is that the grade of the lesion on the abdominal wall is higher than the cancer in the uterus, and PET scintigraphy revealed no findings in favor of metastasis in another region and pathological lymph node involvement as both imaging and pathological results were interpreted negative in favor of synchronous tumor.

Excision with intact margins should be performed in patients diagnosed with scar endometriosis or carcinoma with underlying scar endometriosis. In our case, tumor size in the abdominal wall was $5 \mathrm{~cm}$, without postexcisional abdominal defect. Depending on the size of the tumor, using a mesh or flap to repair the defect in bulky tumor excisions is sometimes necessary.

The most common histological type among reported cases was clear-cell and the second most common type was endometrioidtype. It was reported that in addition to surgical treatment, $74 \%$ and $30 \%$ of cases received adjuvant chemotherapy and radiotherapy, respectively. The most frequently used adjuvant chemotherapy regimen was carboplatin-paclitaxel combination. The mean overall survival rate in 5 years was reported as $40 \%{ }^{(7,8)}$.

Endometriosis-associated abdominal wall cancer is a rare event, and only a few numbers of cases were reported in literature. Adjuvant therapy for these patients is not standardized ${ }^{(9)}$. It is also reported that this condition has extremely poor prognosis. Further studies and long-term results are needed to come up with an optimum treatment and approach.

\section{Ethics}

Informed Consent: Written informed consents were obtained before the study preparation.

Peer-review: Externally peer-reviewed.

\section{Authorship Contributions}

Surgical and Medical Practices: N.T., T.T., Concept: O.Ş., N.T., T.T., Design: O.Ş., N.T., T.T., Data Collection or Processing:
O.Ş., N.T., Analysis or Interpretation: O.S., N.T., Literature Search: O.S., N.T., T.T., Writing: O.S., N.T., T.T.

Conflict of Interest: The authors declare no conflict of interest. Financial Disclosure: The authors declared that this study received no financial support.

Author Disclosure: This study was presented as an oral presentation by Dr. Nedim Tokgozoglu at the Uluslararası Sağlık Bilimleri Üniversitesi Kadın Doğum ve Yenidoğan Günleri, 1821 March 2021.

\section{References}

1. Yela D.A, Trigo L, Pinto CLB. Evaluation of Cases of Abdominal Wall Endometriosis at Universidade Estadual de Campinas in a period of 10 Year. Rev Bras Ginecol Obstet 2017;39:403-7.

2. Khan Z, Zanfagnin V, El-Nashar SA, Famuyideb O, Daftary GS, Hopkins MR. Risk factors, clinical presentation and outcomes for abdominal wall endometriosis. J Minim Invasive Gynecol 2017;24:478-84.

3. Zhang P, Sun Y, Zhang C, Yang Y, Zhang L, Wang N, et al. Cesarean scar endometriosis: presentation of 198 cases and literature review. BMC Womens Health 2019;19:14.

4. Ding Y, Zhu J. A retrospectivereview of abdominal Wall endometriosis in Shanghai, China. Int J Gynaecol Obstet 2013;121:41-4.

5. Gagnier JJ, Kienle G, Altman DG, Moher D, Sox H, Riley D; CARE Group. The CARE guidelines: consensus-based clinical case report guideline development. J Clin Epidemiol 2014;67:46-51.

6. Marques C, Silva TS, Dias MF. Clearcell carcinoma arising from abdominal wall endometriosis - Brief report and review of the literatüre. Gynecol Oncol Case Rep 2017;;20:78-80.

7. Mihailovici A, Rottenstreich M, Kovel S, Wassermann I, Smorgick N, Vaknin Z. Endometriosis-associated malignant transformation in abdominal surgical scar A PRISMA-compliant systematic review. Medicine (Baltimore) 2017; 96:49:e9136. do: 10.1097/ MD.0000000000009136

8. Taburiaux L, Pluchino N, Petignat P, Wenger JM. Endometriosisassociated abdominal wall cancer: a poor prognosis? Int J Gynecol Cancer 2015;25:1633-8.

9. Paulino E, Melo AC, Silva VF. Endometrioid carcinoma arising from an endometriosis-associated abdominal wall scar. Am J Case Rep 2020;21:e922973. doi:10.12659/AJCR.922973 